\title{
Belgeo
}

Revue belge de géographie

1 | 2009

Recent developments in economic geography Miscellaneous

\section{Adrian Favell, Eurostars and Eurocities. Free movement and mobility in an integrating Europe}

ISBN 978-1-4051-3404-0, Blackwell Publishing, 2008, 279 p.

\section{Bruno Meeus}

\section{CpenEdition \\ Journals}

\section{Electronic version}

URL: http://journals.openedition.org/belgeo/8179

DOI: $10.4000 /$ belgeo.8179

ISSN: 2294-9135

Publisher:

National Committee of Geography of Belgium, Société Royale Belge de Géographie

Printed version

Date of publication: 31 March 2009

ISSN: $1377-2368$

Electronic reference

Bruno Meeus, " Adrian Favell, Eurostars and Eurocities. Free movement and mobility in an integrating Europe », Belgeo [Online], 1 | 2009, Online since 19 May 2013, connection on 22 September 2020. URL : http://journals.openedition.org/belgeo/8179 ; DOI : https://doi.org/10.4000/belgeo.8179

This text was automatically generated on 22 September 2020.

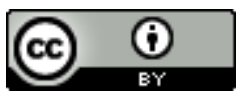

Belgeo est mis à disposition selon les termes de la licence Creative Commons Attribution 4.0 International. 


\section{Adrian Favell, Eurostars and Eurocities. Free movement and mobility in an integrating Europe}

ISBN 978-1-4051-3404-0, Blackwell Publishing, 2008, 279 p.

\section{Bruno Meeus}

\section{REFERENCES}

Adrian Favell, Eurostars and Eurocities. Free movement and mobility in an integrating Europe, ISBN 978-1-4051-3404-0, Blackwell Publishing, 2008, 279 p.

1 The significance of state borders for the mobility of capital, goods, services and people within the central regions of the European Union has continuously diminished throughout the past two decennia, at least in legal terms. Regarding this development, the primary objective of the European Commission nowadays, is to stimulate further the international mobility of the higher educated within the European Union. The main rationale is that the international mobility of persons with considerable amounts of personal capital will contribute to the development of a highly-competitive European region. There is only one problem : international mobility within Western Europe is still very low. Only $2 \%$ of the West-Europeans are currently residing outside their home-countries.

2 Reading "Eurostars and Eurocities" quickly reveals why this privileged migrant group is not that mobile and transnational as too often is assumed or hoped. Supported by ten years of ethnographical research, the author tries to compensate for the rational actor models that are used by the EU when conceptualising transnational mobility. His essay pleasantly intermingles fragments from the life histories of (in total) 60 highereducated Europeans (the "Eurostars") with more theoretical insights on mobility, migration and integration within a unifying Europe. Three local contexts were selected and used for comparison: Amsterdam, for its aura of freedom of norms, London for its 
global cultural cool and Brussels for its concentration of European institutions. The book sketches, through a range of thematic chapters, the main reasons why international mobility within the European Union is still rather exceptional.

Geography plays an important role throughout the book, especially the relationships between the different scales that structure human mobility. In general, it is the nationstate that is still the most significant scale through which human mobility is structured and the author also explains why: "The power of the modern nation-state lies in its ability to standardize and reproduce the lives of its population on a mass scale. To do this, it relies on norms. [It] is thus organized around and for the normal, mainstream way of life: the statistical average that allows the system to manage the present or predict the future [...]" (pp.136). This situation, with the nation-state as the main container of population movements, developed relatively late. Passports and effective border controls only appeared at the end of the nineteenth century, channelling rural populations into the national urban industries or in the national army. The even more recent national welfare institutions were coupled to citizenship rights and these were mobile within the boundaries of the country but never transferable outside. For the better-off, there was and still is little reason to move outside this national system at all. They are incorporated very well into the high ends of the system, have acceptable career opportunities and a local network of friends and family. Their parents play a considerable role in their household (they for instance look after the grandchildren after school) and land and real estate pass from generation to generation. However, social mobility within the national system is rather hard, especially in countries with strong centralized social mobility structures such as France and Great Britain. Young ambitious people, coming from the provinces, see the competitive route through the capital city often blocked due to the monopolizing of elite facilities by the national elites. Especially these people opt for a different career path than the one within the borders of the nation-state. Their step towards an international future, a jump of scale, must be interpreted as a move into a new field, in which the values, rules and hierarchies are not clearly established yet. What the Eurostars appreciate most in their situation of international mobility, is a special form of freedom. "What everyone [the Eurostars] is talking about here is freedom from the nation-state, a denationalized freedom" (pp. 9).

4 The cities where they arrive, however, are also part of national systems and further integration into local networks often means becoming used to national habits, again. An excellent example in the book describes how the Eurostars have to engage with the after work drinking behaviour of British Londoners. It is typical British and for maintaining the social networks with their British colleagues there is no alternative. Local social networks in general are difficult to enter since they often date back from high-school. Their importance is high, yet. Access to the nationals' network for instance means access to information on local cheap housing, which is crucial in London and especially in Amsterdam.

5 At the same time, the transition towards a second life phase slows down movement, due to long term life planning dilemmas. Being solo, it is easy to weigh the pros and cons of international mobility. Being a household head raising children, international mobility is more problematic. How much stability does a child need ? In addition, being hyper mobile and at the same time building up a secure pension does not rhyme very well since rights to welfare still are strongly nationalized. Long term financial planning 
becomes difficult and often the provision of long term welfare benefits rests on the willingness of some multinational companies. As such, the logic of free mobility is fundamentally different from the logic of traditional immigration. "Typically, the longterm benefits to immigration outweigh the often sharp short-term costs. A new life in a new country, social mobility for your children, citizenship and full integration, will one day offsets the pain of leaving, the difficulties of moving, or the downgrading of skills and social standing that is the most typical trajectory of immigrant workers." (pp. 205) A denationalized mobility, on the other hand, compels a person to break the social contract of the national welfare state. Currently, however, the new European space does not guarantee anything the nation-state used to.

This clear and resounding message is addressed towards the designers of the European human mobility space. One can also formulate the message as follows : migrant workers are not a floating population who can be treated as other "factors of production". The economies of migrant work are not "beyond space" but localised in specific social and spatial settings. With this primary message, the book sets new standards for migration policy and research, focusing on aspects of social reproduction and showing the vulnerability of mobility. Notwithstanding the combination of lots of theoretical insights with everyday life ethnographic data gathered in different social and spatial contexts, the author chooses for good readability. This undeniably is an important book that hopefully will resonate in the policy-making rooms of the European Union.

The book stimulates a lot of further thoughts. In many occasions, the author compares the life of the Eurostars in different cities. As such the locations are played out against each other and Brussels then often appears in the story as a city that "works" for many of the Eurostars. Due to the lack of one homogeneous national Belgian population in the city, Brussels seems to be the most truly cosmopolitan. The author also argues that, compared to London or Amsterdam, the Eurostars' income makes it possible to reach a much higher living standard in Brussels. One could wonder about the relationship between both observations. Probably, due to the relative strong income position of the Eurostars' in Brussels, their influence upon the city is also proportionally bigger than in London or Amsterdam. Currently, cheaper housing market segments in Brussels disappear in the more favourable locations due to gentrification and commerce is more and more focused on higher income groups. The "freedom" of the Eurostars can be bigger in Brussels, but becomes a bit doubtful when considering the large contingents of low-skilled and often not-EU migrants, that also look for housing in the nice neighbourhoods but have to be satisfied with the bad quality leftovers sometimes even far beyond the city (see Van Criekingen, 2006). They need the redistribution power of the national state the most. Although the important weight of social relations structured through the nation-state seems to discourage the transnational mobility within the EU, the book therefore may not become the argumentation for the further individualization of welfare rights, formerly organised on the national state level, just for the good of increasing mobility (see for an analysis of the increasing fragmentation of solidarity in a Brussels' context: Meert \& Stuyck, 2008). The author never really takes a clear standpoint in the discussion about the necessity of stimulating international mobility, nor in its relationship with the "competitiveness" of the European Union. In case intra-EU mobility needs to be encouraged to increase the level of competence of the region, it seems, in any case, that at the same time welfare rights organised on a European level should be developed; not only for the Eurostars working 
at the high end of the labour market, but also for the mobile population performing the less attractive jobs in each of the Eurocities.

\section{BIBLIOGRAPHY}

MEERT H. \& STUYCK K. (2008), “Homelessness, Post-Fordist Solidarity and Disciplining Urbanism", in DOHERTY J. \& EDGAR B. (Ed.), In my Caravan, I feel like Superman, Essays in honour of Henk Meert, pp. 145-170.

VAN CRIEKINGEN M. (2006), "What is happening to Brussels' inner-city neighbourhoods? Selective migration from areas undergoing gentrification”, Brussels Studies, 1, pp 1-21. 